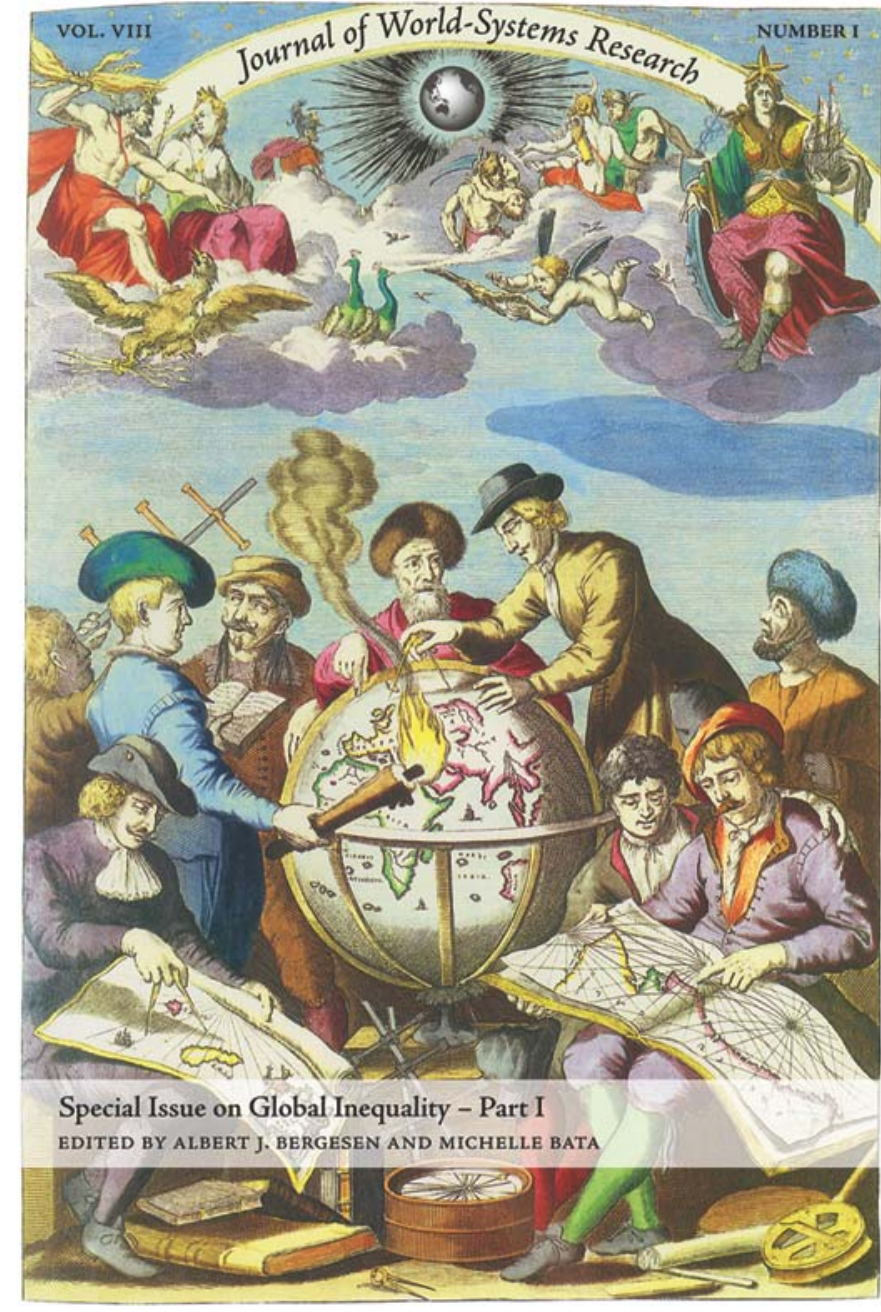

ABSTRACT

Most studies consider the trends of incom inequality between nations and between individuals within nations separately. In this paper, we analyze between-nation and within-nation inequality together. We find that income inequality both within and between nations has been increasing over time. Furthermore, we show that the rate of change for both are synchronous. We speculate that this synchronicity is due to the formation of a global class system.

\section{Global and National Inequality: Are They Connected?}

\section{Albert J. Bergesen \\ Michelle Bata}

Tnequalities between individuals (within social systems) and between nations 1 (within the world-system) seem to be the principal components of global inequality. They are, though, very rarely considered together. Income inequality has been explained in terms of economic growth (Kuznets 1955, Deininger and Squire 1996), demographic change (Gustafsson and Johansson 1999, Crenshaw et al. 1997, Nielsen 1994, Kuznets 1955), political democracy (Bollen and Jackman 1985) and sector dualism (Alderson and Nielsen 1999, Nielsen 1994), while others suggest it is influenced by foreign capital penetration and trade (Alderson and Nielsen 1999, Dixon and Boswell 1996, Firebaugh 1996). For a summary of this research see Table I.

On the other hand, research on the global gap between rich and poor countries has been primarily concerned with identifying the gap and debating whether between-nation inequality is likely to converge (Summers et al. 198I, Berry et al. 1983, Firebaugh 1999) or diverge (Passè-Smith 1993, Korzeniewicz and Moran 1997). In all this research though, little attention has been given to the question of whether the gap between nations is correlated with, or has an effect upon, the gap between individuals within those countries. On their own, questions of national income inequality and the global gap are obviously important, but what we would like to focus upon here is the possible interrelationship between these two aspects of global inequality.
Albert J. Bergesen

University of Arizona

Department of Sociology

Social Science Building, Room 400

Tucson, AZ 85721

albert@email.arizona.edu
Michelle Bata

University of Arizona

Department of Sociology

Social Science Building, Room 400

Tucson, AZ 85721

bata@u.arizona.edu http://w3fp.arizona.edu/soc/default.asp inequality within non-core countries reaches its peak. We conclude by hypothesizing that the observed convergence might result from global opposition (i.e., increasing global inequality between nations) producing national cohesion, causing the observed lessening of income inequality scores within non-core countries.
JOURNAL OF WORLD-SYSTEMS RESEARCH, VIII, I, WINTER 2002, I30-I44 Special Issue on Global Inequality - Part I

http://jwsr.ucr.edu

ISSN $1076-156 \mathrm{X}$

(C) 2002 Albert J. Bergesen and Michelle Bata 
Table 1 - Summary of Inequality Research

\begin{tabular}{|c|c|c|c|c|c|}
\hline Authors & $\begin{array}{l}\text { Year of } \\
\text { Study }\end{array}$ & $\begin{array}{l}\text { Time } \\
\text { Frame }\end{array}$ & $\begin{array}{l}\text { Sample Size } \\
\text { (countries) }\end{array}$ & $\begin{array}{l}\text { Inequality } \\
\text { Measure }\end{array}$ & Key Variables \\
\hline \multicolumn{6}{|c|}{ Within-Nation Inequality } \\
\hline Nielsen & 1994 & c. 1970 & 56 & $\begin{array}{l}\text { Gini and income } \\
\text { share of top } \\
\text { quintile }\end{array}$ & $\begin{array}{l}\text { secondary school enrollment }(-) \\
\text { rate of population increase }(+) \\
\text { sector dualism }(+) \\
\text { \% labor force in agriculture }(-)\end{array}$ \\
\hline $\begin{array}{l}\text { Alderson and } \\
\text { Nielsen }\end{array}$ & 1999 & $1967-1994$ & 88 & Gini & $\begin{array}{l}\text { secondary school enrollment }(-) \\
\text { rate of population increase }(+) \\
\text { sector dualism }(+) \\
\% \text { labor force in agriculture }(-) \\
\text { foreign investment stock }(+) \\
\text { foreign investment rate }(-) \\
\text { Marxist/Leninist regime }(-)\end{array}$ \\
\hline $\begin{array}{l}\text { Gustafsson and } \\
\text { Johansson }\end{array}$ & 1999 & 1966-1994 & 16 & Gini & $\begin{array}{l}\mathrm{GDP} / \mathrm{pc}(-) \\
\% \text { labor force in industry }(-) \\
\text { imports }(+) \\
\text { public consumption }(-) \\
\text { unions }(-) \\
\text { youth dependency }(-)\end{array}$ \\
\hline \multicolumn{5}{|c|}{ Between-Nation Inequality } & Trend \\
\hline Summers et al. & 1981 & $1950-1975$ & 106 & Gini & convergence \\
\hline Berry et al. & 1983 & $1950-1977$ & 124 & Gini, Theil & convergence \\
\hline Firebaugh & 1999 & $1960-1989$ & 120 & $\begin{array}{l}\text { Gini, adjusted for } \\
\text { PPP and } \\
\text { weighted by } \\
\text { population size }\end{array}$ & convergence/no change \\
\hline Passe-Smith & 1998 & 1960-1993 & 112 & $\begin{array}{l}\text { Growth rates, } \\
\text { gap analysis }\end{array}$ & divergence \\
\hline $\begin{array}{l}\text { Korzeniewicz and } \\
\text { Moran }\end{array}$ & 1997 & 1965-1992 & 121 & Gini, Theil & divergence \\
\hline
\end{tabular}

We begin with the observation that these inequality processes operate within two different social systems - one national and one international—and that the theoretical dynamics driving these two dimensions of global inequality may not be the same. The most well understood dynamics are the national ones, being the object of stratification theory from classical economics through Marx and Weber to present empirical research. From differences in human capital to modes of production, class and status relations, a rich literature has arisen to account for domestic disparities in wealth and income. The idea of class, as aggregates of national income levels, or functionally defined economic positions (owning/ controlling the means of production) has been theorized to operate within a larger holism of societal, or mode of production, dynamics, where different economic systems have been hypothesized to generate different class systems and resultant inequalities. But when it comes to such class-like categories for the world-system, theory is much less developed. As such, there is less of a sense of how a world-system would function as a social system replete with global inequalities generated by the holistic dynamics of the world economy. This is due, in good part, to the fact that the prevailing model of the world-system is in Smithian terms as a global division of labor (Wallerstein 1974) and while exchanges between core and peripheral zones are thought to be unequal, thereby disadvantaging developing countries, there are as yet no serious ideas about such globally holistic entities as global classes or a global mode of production. As a result, hypotheses about global stratification in the sense of relations between global classes do not exist and most of the research that has been done is largely descriptive. This is important, of course, but now that a body of literature and data sets on inequalities within and between countries are available, we can turn our attention to more complex hypotheses about how inequality within and between might be causally interconnected.

\section{THE TWO INEQUALITIES}

We begin with the assumption that the gap between persons within countries and the gap between countries themselves may have separate logics such that a widening gap within nations may not be correlated with a widening gap between nations. For example, one can imagine an egalitarian world-system where inequality between countries or zones of countries, like the core and periphery, would be low, while at the same time they could vary in terms of how that wealth is distributed. Therefore, there could be (I) high degrees of international and national inequality: great distances between countries and between persons within those countries. The opposite of this would be (2) a global condition of low inequality between countries and persons. This would represent the idealized condition of a more egalitarian world order. There is also (3) the possibility of high inequality between countries accompanied by low inequality between individuals within those countries, and the opposite condition: (4) low inequality between countries and high inequality between persons. These possibilities raise the question of whether such inequalities systematically co-vary 
Table 2 - Data Summary

\begin{tabular}{|c|c|c|}
\hline Description of the Variable & Measurement & Data Source \\
\hline $\begin{array}{l}\text { Within-nation Income } \\
\text { Inequality }\end{array}$ & Gini Coefficient & $\begin{array}{l}\text { Deininger and } \\
\text { Squire, } 1998\end{array}$ \\
\hline $\begin{array}{l}\text { Between-nation Income } \\
\text { Inequality }\end{array}$ & $\begin{array}{l}\text { Absolute Gap of GDP/pc Between Core } \\
\text { and Non-Core Countries (Core GDP - } \\
\text { Non-Core GDP) }\end{array}$ & $\begin{array}{l}\text { Summers and } \\
\text { Heston, } 1991\end{array}$ \\
\hline
\end{tabular}

Sample $(n=72)$

Core:

Australia, Austria, Belgium, Canada, Denmark, Finland, France, Germany, Ireland, Israel, Italy,

Japan, Luxembourg, Netherlands, New Zealand, Norway, Spain, Sweden, Switzerland, United Kingdom, United States

\section{Non-Core:}

Algeria, Bahamas, Bangladesh, Barbados, Bolivia, Brazil, Bulgaria, Chile, China, Colombia, Costa Rica, Czech Republic, Dominican Republic, Egypt, El Salvador, Gabon, Ghana, Greece, Guatemala, Honduras, Hong Kong, Hungary, India, Indonesia, Iran, Jamaica, Jordan, Korea

Malaysia, Mauritius, Mexico, Morocco, Nigeria, Pakistan, Panama, Peru, Philippines, Poland, Portugal, Puerto Rico, Romania, Seychelles, Singapore, Sri Lanka, Tanzania, Thailand,

Tunisia, Turkey, Venezuela, Yugoslavia, Zambia

and, more interesting, whether one of these gaps or inequalities might have a determinate affect upon the other. We will consider each of these issues separately. To do this we turn to some data on the co-variation of the global gap and income inequality.

\section{DATA AND ANALYSIS}

To examine the relationship between the international gap and national inequality we created a data set of 72 countries from 1965 to 1990. The first variable, which we refer to as the global gap, is created by taking the absolute difference between the GDP/pc for core and non-core nations (see Table 2). The second variable, which we refer to as the national gap, are Gini coefficients measuring national income inequality, and are taken from Deininger and Squire (1996).

We begin with the simplest question: do the two inequalities move in the same direction? That is, when the gap between countries widens does the gap
Figure 1 - GDP/pc for a Sample of Core and Non-core Countries, $1965-1990(n=72)$

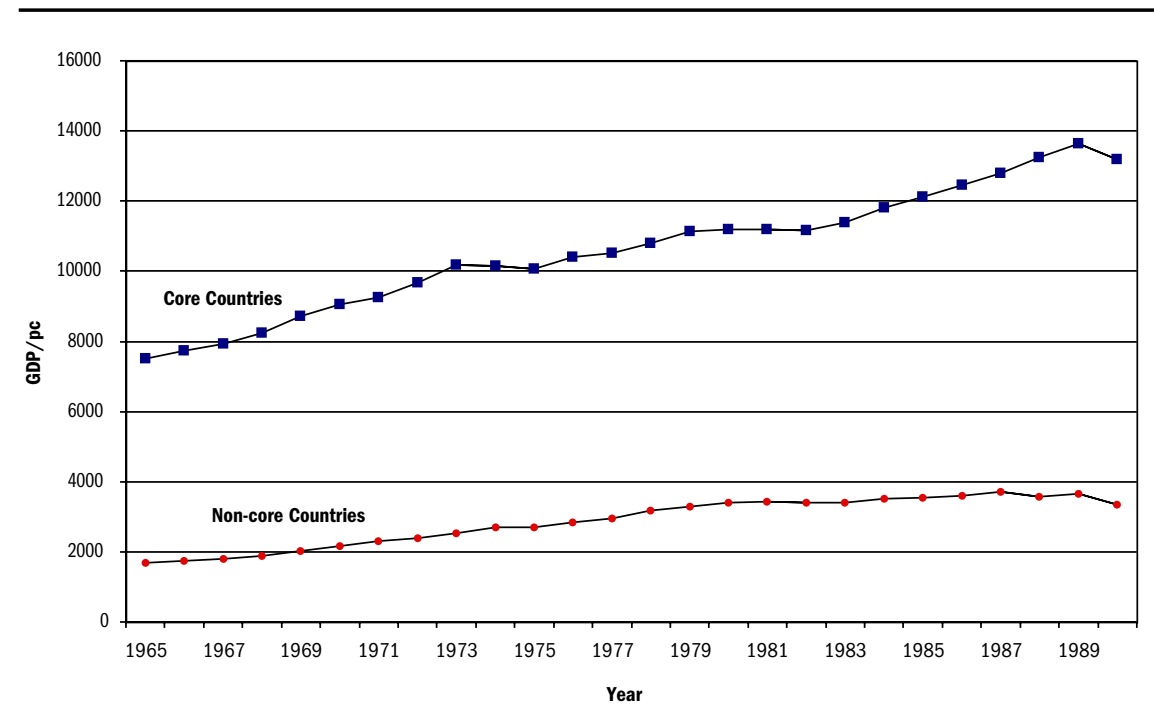

between individuals within those countries also widen, and conversely when the gap between lessens does the inequality within lessen. ${ }^{1}$

Figure I shows that between 1965 and 1990 the level of GDP/pc is growing for both core and non-core countries, but the rate is higher for the core, creating a growing global gap, which is plotted in Figure 2. One can see that, in general terms, the global gap between countries falls into three periods in terms of its rate of growth. The first is from 1965 to 1973. Here the gap is growing. During the second period from 1974 to 1982 the rate of growth noticeably slows, and in the final period from 1983 to 1990 the global gap starts to widen again.

Figure 2 also presents data for the average income inequality scores for this same set of countries, and Figure 3 presents data on the rate of growth of both the global gap and national income inequality for these three periods. These data show that the two inequalities move together. When the rate of growth for the

1 World-system theory, of course, posits a tri-partite division of the world into core, semiperiphery, and periphery, but our interest is in a gap, not a multitude of gaps, and so we only look at the structural inequality between the rich countries of the core and the rest of the world. 
Figure 2 - The Absolute GDP/pc Gap and Average Gini Income Inequality Scores, $1965-1990(=72)$

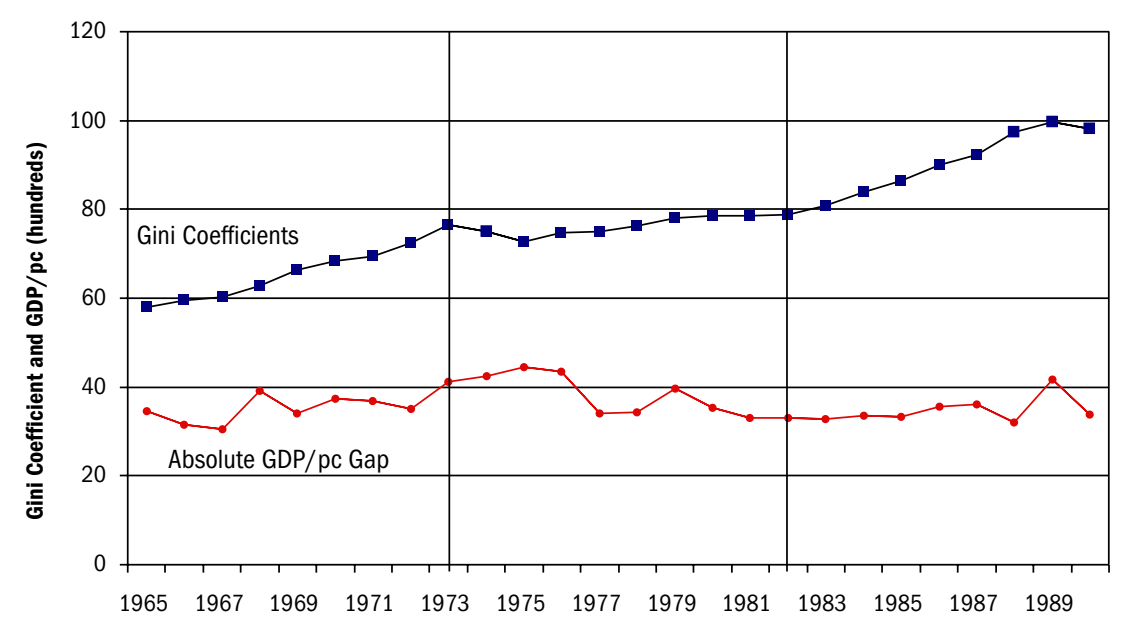

Year

$\longrightarrow$ Absolute GDP/pc Gap between Core and Non-Core Countries $\longrightarrow$ Average Gini Income Inequality Scores

global gap increases so does national income inequality; when the global gap declines in its rate of growth income inequality actually becomes negative. Stated otherwise, when the gap between core and non-core countries widens the gap between people widens, and when the rate of growth of gap between these countries slows so does the rate of national inequalities slow down. Therefore this preliminary data analysis supports the hypothesis that the two inequalities move together in the same direction and provides the first evidence we know of that the two components of global inequality systematically co-vary.

These findings support something like an "expanding universe" model: when categories of countries move apart, individuals move apart; when those countries are closer, individuals are closer. Income inequality measures are of dispersions while the global gap is about the distance between specific groups, categories, or classes of countries. One could compute a global Gini index (with countries rather than individuals as the unit of analysis) that would show the relative dispersion of all countries but this might not capture the more sociological notion of "class" which entails ideas about functional relations between groups of individuals, or if the term were to be applied to the world-system, between groups of whole countries.
Figure 3 - Rate of Change for Global and National Inequalities, 1965-1990 (n=72)

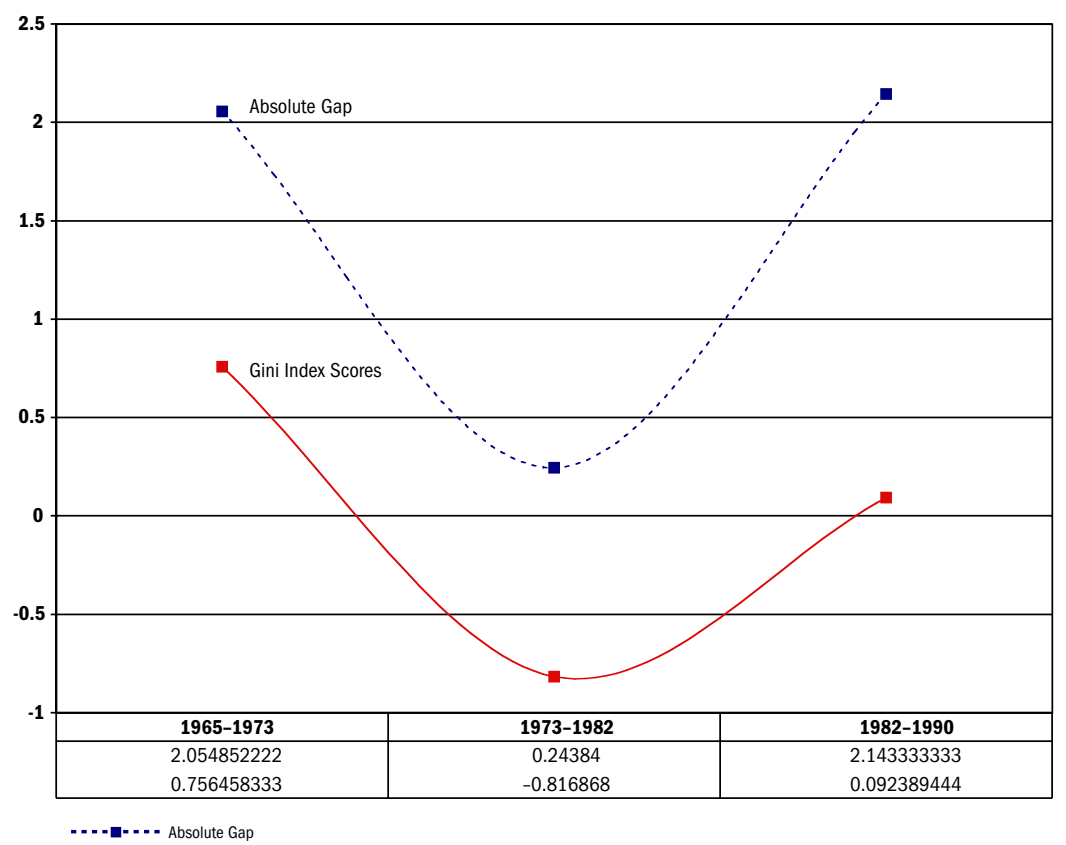

Absolute Gap

This idea of something like global class analysis can mean different things. The internationalization of capitalism has led some to inquire as to whether the capitalist class is transnational in character and given the national rootedness of labor and the trans-national mobility of global capital, whether such globalized capital has an advantage over labor in today's world economy. This is probably the prevalent view of globalizing capitalism, but there is another perspective on class on a global scale that we want to explore here in light of some of our data that there are actually periods when the global and national gaps move in opposite directions.

\section{CAN GLOBAL INEQUALITY PRODUCE NATIONAL EQUALITY?}

Within this larger trend of co-variation there is some evidence of inequalities moving in opposite directions for non-core countries. That is, when the global gap narrows income inequality scores increase. This can be seen in Figure 4, which presents average income inequality scores decomposed for our sample of core and non-core countries. Over this whole period the global gap only reverses 
Figure 4 -The Absolute Gap versus Average Gini Index Scores for Core and Non-core Nations, 1965-1990 ( $\mathrm{n}=72$ )

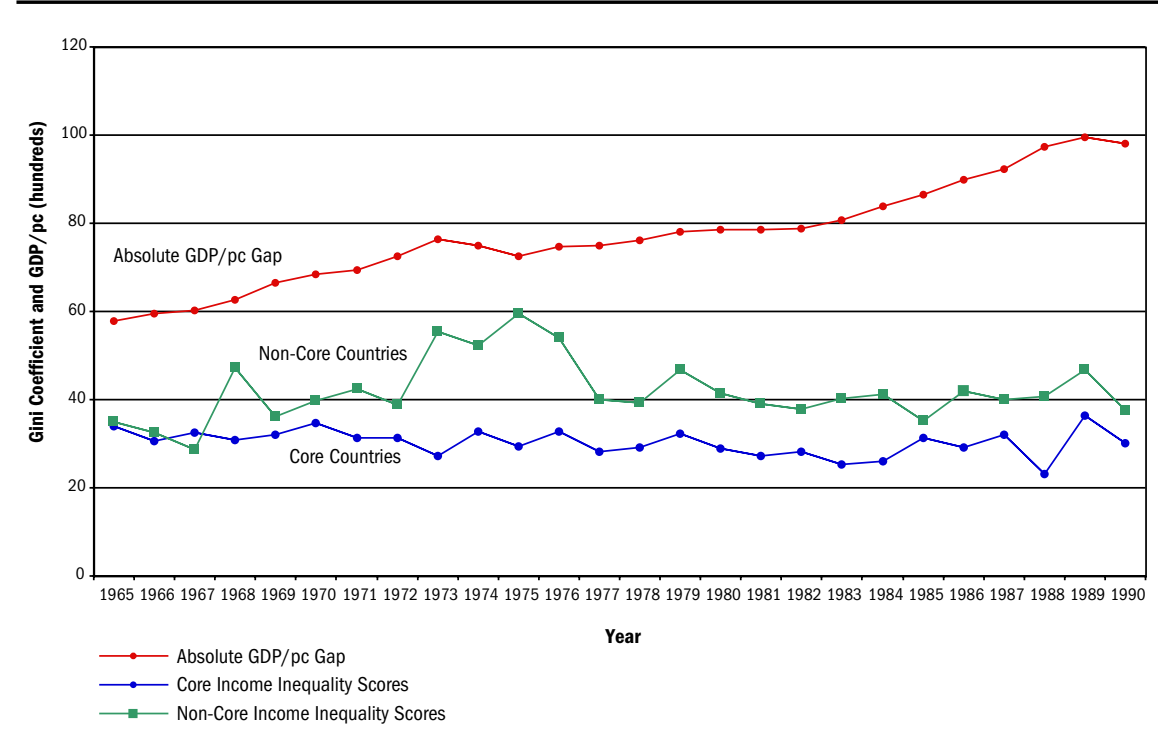

itself for more than one year in the early I970s. Interestingly, this is also the time when income inequality in non-core countries reaches its highest point (see Figure 4). We caution that the number of years here is small and these relationships may be spurious. Nonetheless, it is the case that from 1965 through 1990 the global gap only decreased for more than one year during one period of time and that was precisely the time that domestic inequality for non-core countries had a sustained spike and reached its high point.

What we would like to do now is to use this evidence-qualified as it is-to speculate a little upon what sort of globological dynamics might be producing this effect. We begin with the observation that income inequality research remains bound within a national framework. When speaking of "global" or "international" inequality the reference is to an average degree of income inequality across countries. In this sense global inequality is not about something like a global gap between whole sectors of the world system as if they were something like global social classes. Studies of the global gap are not considered in globological terms either, nor is the gap's possible effect upon income inequality studied. Each research tradition studies inequality as a separate entity.

One would hope that world-system theory would offer propositions linking the global gap to national inequalities, and to the extent that dependency relations have effects upon income inequality, then the global should be considered an independent variable with which to predict income inequality rates. But theoretically, world-system theory does not entertain notions of distinctly collective entities like social classes at the world level in good part because it remains mired in the aggregated individualism of the core-periphery division of labor model which is devoid of such structural entities (Brenner 1977).

The emergence of ideas about class structure at the global level may be on the horizon, though, as world-system theory seems to be widening its frame of reference. First, the origin of patterns of inter-societal networks, or world-systems, is being located further and further back in human history (Abu-Lughod I989, Chase-Dunn and Hall 1997, Frank 1998) and second theory is inching toward a post-sociological framework to conceptualize world historical dynamics (Frank 1998, Bergesen I995C). Here the growing suspicion is that the traditional stages of development from hunter-gatherer through slavery and feudalism to capitalism represents a Euro-centric reading of world history which masks the larger dynamics of the world-system as a collective whole which now appears to have much more structural constancy over time than initially thought.

Rooting global interconnectedness back in time has been easier than identifying the structures that characterize the global totality as a collective formation. But if there is a singularity of historical continuity then there may also be a singularity of social process. Exactly what such a set of globological structures and processes would look like is still unclear, although at a minimum Frank (1998) strongly suggests that shifting balance of payments structures affects the creation of hegemonic centers across all previously theorized modes of production. While there is probably more global social structure than presently theorized, the precise nature of such global entities as global classes or global modes of production has yet to be clearly identified, and in that regard we would like to re-examine our data in light of a distinctly globological perspective on what might be driving the covariation between the two gaps.

For instance, if we extrapolate traditional sociological reasoning that component structures are usually under the control of a larger encompassing structure, then the inequality of the world-system-as indicated by the gap between core and non-core countries-would seemingly constitute the determinate context for variation in such sub-global structures as patterns of national inequality. The underlying logic here is the classic sociological assumption of the priority of the larger encompassing framework. This idea was captured nicely by Marx, who argued something to the effect that it is not individuals buying and selling that creates capitalism, but capitalism that makes individuals buy and sell. In the case of global inequality the argument would be: it is not inequality between individuals that makes for a global inequality between countries, but global inequality that makes for an inequality between individuals within those countries. The 
global system, then, acts as a totality. That is, has collective dynamics that can be considered emergent properties at the global level that are not reducible to national levels of social structuring. The world-system has a life of its own, much like a national economy has dynamics that are independent of those of its constituent firms, labor pools, and sources of capital. In this sense the world-system can be considered a Durkheimian sui generis social fact, a functioning social system at the distinctly global level of human structuration. In that regard it probably has its own classes, such as the groupings identified in world-system theory as core, periphery, and semi-periphery.

While present understanding of such a global social system is not as advanced as the theory of societal social systems, we will assume that such a global social system exists, and that its non-reducible global dynamics have determinate effects upon national social systems in analogous ways to how societal social systems have effects upon their institutions, organizations, regions, cities, and neighborhoods. That is, what has been assumed for sociology, that the collective dynamics of the whole directs, influences, or shapes the collective properties of lower levels of social order, is assumed here for the global system, and one lower level of social order would be the national patterns of income inequality we have observed in this research.

The world economy can also be characterized as something like a distinctly global model of production, which is the traditional sociological characterization of an economic system in terms of power, force, and control. This is a way of articulating emergent properties that are more than the aggregated individualism of the neo-classical economic model. In the societal case the role of power and social class enters the picture with the idea that certain segments of the population own/control (a legal, political, or social relation, not a narrowly economic relation) the means of production requiring others to sell their labor for a wage. As a result of introducing such socio-political relations into the earlier consensual model of the free exchange of labor for capital, voluntary exchange relations were replaced by power and class relations in the emerging sociological model of the economic process.

It was also assumed that because of these relationships there was tension and antagonism between the classes. Furthermore, classes were sometimes aware of their collective condition (class consciousness) and were capable of being not just a class in themselves but also a class for themselves, and therefore capable of varying degrees of agentic class action. With this assumption social change was introduced into the more atomistic and mechanical economic model, where the division of labor, now re-cast as the mode of production, was theorized to have properties such as class relations, domination, and hierarchy, which animated action by classes to defend their material interests within the larger economic system.
Finally, it seems reasonable to assume that if such properties as class divisions, class consciousness and class agency exist, there is no reason to believe they are limited to only national economic systems. If the global economy exists as an emergent collective entity with properties of its own, there is no reason why some of the characteristics of economic systems identified at the national level should not also exist at the global level. When this assumption is made then what until now have only been seen as economic zones, or core and non-core areas within the Smithian/Wallersteinian division of labor, can now be re-seen as rudimentary outlines of global classes within something like a global mode of production. As Marx thought sociologically about the Smithian division of labor within countries, so we must now start to think globologically about the Wallersteinian division of labor between countries.

In sum, this speculation about class-like entities at the distinctly world level is the start of a second phase of theoretically modeling the inequality process of the world-system, and it advances on three tracks: (I) the historical push backward identifying earlier and earlier intersocietal connections (Boswell and Chase-Dunn 1999, Frank 1998, Abu-Lughod 1989, Chase-Dunn and Hall 1991, Chase-Dunn and Hall 1997, Sanderson 1995, Chew 200I); (2) the resultant erosion of received Eurocentric theoretical structures from Marx and Weber to Braudel and Wallerstein which had privileged European development over the rest of the world and particularly China (Pomeranz 2000, Frank 1998, Blaut 1993, Wong 1997, Chew 200I, Goody 1996); and (3) the movement toward conceptualizing the singularity of world historical structures and processes (Frank 1998, Bergesen 1990, 1995a, 1995b, 1995c).

\section{HOW THE GLOBAL MIGHT AFFECT THE NATIONAL}

Let us suppose there are two stratification systems in which all the world's people are enmeshed. One is national-the classic division of society into classes that we are familiar with since at least Marx, if not before - and the other our postulated global mode of production with core/non-core as the preliminary estimation of global class structure. ${ }^{2}$ This, of course, is our two inequalities but put now in class-like terms, where we assume that the dynamics of income inequality reflects aspects of societal stratification and the absolute GDP/pc gap reflects the dynamics of global stratification. We also assume that global dynamics take precedent over societal ones, which means that changes in the global

2 The place, role, or reality of the world-system theoretic concept of the semiperiphery will be temporarily held in abeyance in this analysis. 
stratification system should have noticeable effects upon the societal system.

Therefore, if the absolute global gap is large, it stands to reason that withinsocietal classes (like capital or labor) would experience their global location in a more pronounced way than if the absolute gap was small. Capital and labor in the non-core, for example would stand closer together in a common zonal opposition to the core in a more polarized world-system. The opposite would also be true. If the global gap were to narrow the unity pressure of global location would lessen allowing intra-societal stratification to predominate. This appears to be what we found in the data for the early 1970s. As Figure 4 shows, income inequality for non-core nations only spikes in a sustained way when the global gap declines. All of this suggests a somewhat counter-intuitive set of dynamics. When the global gap widens the national inequality for non-core countries narrows and when the global gap narrows, national inequality for non-core countries widens. On the surface it would appear as if the two stratification systems are working against each other. The solution to the mystery maybe this: the widening global gap polarizes the international system, such that material interests and class consciousness become increasingly globalized in this condition. This now means one stands in an increasingly objective global position vis-à-vis the other global class as opposed to the social classes within the national formation. This has two consequences. First, one's life fate is objectively dictated less and less by one's national class position and more and more by one's global class position. Being in the non-core matters more and more, and takes precedent over social class positions within the national/societal formation.

The process should work in the other direction as well. As the global gap narrows, the global class system becomes more egalitarian and hence less polarized, and objective global class position become less and less important in structuring individual lives, and therefore local positions ever more important. The great division of the world between haves and have-nots shrinks, and is less and less the key factor structuring local life. And, if it matters less and less what part of the world one is from because all parts of the world are becoming more and more alike, then local class structures and localized polarizations are allowed to matter more and more. The imperative that the expanding global gap creates for national classes and local social groups to stand shoulder to shoulder in common opposition now disappears for it is no longer necessary and as such differences within countries can, and should, rise. One indicator of such local class divisions mattering more would be an increase in income inequality. The old social psychological adage that the greater the external threat the greater the internal cohesion, has an analog here: the greater the global gap (threat) the greater the internal cohesion (decline in income inequality). And, interestingly, this is precisely what appears for non-core countries in Figure 4.

\section{SUMMARY}

We started out investigating the global and national trends in income inequality. Upon examining some data, though, it appears as if there are various synchronizations in these two sets of gaps/inequalities. The clearest is the insynch growing and slowing of global gap/income inequality. But there is also some evidence that these gaps can, under some circumstances, move in opposite directions. The only period of more than one year in which the global gap declines, it turns out, is the only period when national inequality for non-core countries reaches its highest points. We go on to suggest global opposition produces national cohesion, and a lessening of that opposition raises national differences, as seen in the rise in non-core inequality scores, observed only when the global gap lessens.

\section{REFERENCES}

Abu-Lughod, Janet. 1989. Before European Hegemony: The World System A.D. 1250-1350. New York: Oxford University Press.

Alderson, Arthur S. and Francois Nielsen. 1999. "Income Inequality, Development, and Dependence: A Reconsideration." American Sociological Review 64: 606-63I.

Bergesen, Albert J. 1990."Turning World-system theory on its Head" Theory, Culture and Society. 7:67-8I.

Bergesen, Albert J. 1995a. "Deep Ecology and Moral Community” Pp. 193-213 in Rethinking Materialism: Perspectives on the Spiritual Dimension of Economic Beabvior, edited by Robert Wuthnow. Grand Rapids, Mich.: Erdmanns.

Bergesen, Albert J. 1995b. “Eco-Alienation.” Humboldt Journal of Social Relations 2I:I:I-I4.

Bergesen, Albert J. 1995c. "Lets be Frank About World History." Pp. I8I-I9I in Civilizations and World-Systems: Studies of World-Historical Change, edited by Stephen K. Sanderson. Walnut Creek, Calif:: Altamira.

Berry, Albert, Francois Bourguignon, and Christian Morrisson. 1983. "Changes in the World Distribution of Income between 1950 and 1977." The Economic Journal 93: $33 \mathrm{I}-350$.

Blaut, J. M. 1993. The Coloinizer's Model of the World: Geographical Diffusionism and Eurocentric History. New York: Guilford.

Bollen, Kenneth A. and Robert W. Jackman. 1985. "Political Democracy and the Size Distribution of Income." American Sociological Review 46: 65I-659.

Boswell, Terry, and Christopher Chase-Dunn. 1999. The Spiral of Capitalism and Socialism: The Decline of State Socialism and the Future of the World-System. Boulder, Colo.: Lynne Reinner.

Brenner, Robert L. 1977. "The Origins of Capitalist Development: A Critique of NeoSmithian Marxism." New Left Review 104, 25-92. 
Chase-Dunn, Christopher, and Thomas D. Hall, eds. 1991. Core/Periphery Relations in Precapitalist Worlds. Boulder, Colo.: Westview.

Chase-Dunn, Christopher, and Thomas D. Hall. 1997. Rise and Demise: Comparing World-Systems, Boulder, Colo.: Westview.

Chew, Sing, 200I. World Ecological Degradation: Accumulation, Urbanization, and Deforestation, 3000 B.C-A.D. 2000. Walnut Creek, Calif.: Altamira.

Crenshaw, Edward, Ansari Ameen, and Matthew Christenson. 1997."Population Dynamics and Economic Development: Age-Specific Population Growth Rates and Economic Growth in Developing Countries, 1965-1990." American Sociological Review 62: 974-984.

Deininger, Klaus and Lyn Squire. 1996. "A New Data Set Measuring Income Inequality." The World Bank Economic Review 10:565-59I.

Dixon, William J. and Terry Boswell. 1996. "Dependency, Disarticulation and Denominator Effects: Another Look at Foreign Capital Penetration." American Journal of Sociology 102: 543-562.

Firebaugh, Glenn. 1996. "Does Foreign Capital Harm Poor Nations? New Estimates Based on Dixon and Boswell's Measure of Capital Penetration." American Journal of Sociology 102: 563-575.

Firebaugh, Glenn. 1999. "Empirics of World Income Inequality." American Journal of Sociology 104: 1597-1630.

Frank, Andre Gunder. 1998. ReOrient: Global Economy in the Asian Age. Berkeley: University of California Press.

Goody, Jack. 1996. The East in the West. Cambridge: Cambridge University Press.

Gustafsson, Bjorn, and Mats Johansson. 1999."In Search of Smoking Guns: What Makes Income Inequality Vary over Time in Different Countries?” American Sociological Review 64: 585-605.

Korzeniewicz, Roberto Patricio and Timothy Patrick Moran. 1997."World Economic Trends in the Distribution of Income, 1965-1992." American Journal of Sociology IO2: 1000-IO39.

Kuznets, Simon. 1955. "Economic Growth and Income Inequality." American Economic Review 45: I-28.

Nielsen, Francois. 1994. "Income Inequality and Industrial Development: Dualism Revisited." American Sociological Review 59: 654-677.

Passè-Smith, John T. 1998. "The Persistence of the Gap Between Rich and Poor Countries: Taking Stock of World Economic Growth, 1960-1993," in Development and Underdevelopment: The Political Economy of Global Inequality, edited by Mitchell A. Seligson and John T Passè-Smith. Boulder, Colo.: Lynne Reiner

Pomeranz, Kenneth. 2000. The Great Divergence: China, Europe, and the Making of the Modern World Economy. Princeton: Princeton University Press.

Sanderson, Stephen K., ed. 1995. Civilizations and World-Systems: Studying WorldHistorical Change. Walnut Creek, Calif.:Altamira.

Summers, Robert, Alan Heston, Bettina Aten, and Daniel Nuxoll. 1994. Penn World Table (PWT) Mark 5.6a Data. Center for International Comparisons, University of Pennsylvania.
Wallerstein, Immanuel. 1974. The Modern World-System: Capitalist Agriculture and the Origins of European World-Economy in the Sixteenth Century. New York: Academic Press.

Wong, R. Bin. 1997. China Transformed: Historical Change and the Limits of European Experience. Ithaca: Cornell University Press. 
Chase-Dunn, Christopher, and Thomas D. Hall, eds. 1991. Core/Periphery Relations in Precapitalist Worlds. Boulder, Colo.: Westview.

Chase-Dunn, Christopher, and Thomas D. Hall. 1997. Rise and Demise: Comparing World-Systems. Boulder, Colo.: Westview.

Chew, Sing, 200I. World Ecological Degradation: Accumulation, Urbanization, and Deforestation, 3000 B.C-A.D. 2000. Walnut Creek, Calif.: Altamira.

Crenshaw, Edward, Ansari Ameen, and Matthew Christenson. 1997. "Population Dynamics and Economic Development: Age-Specific Population Growth Rates and Economic Growth in Developing Countries, 1965-1990." American Sociological Review 62: 974-984.

Deininger, Klaus and Lyn Squire. 1996. "A New Data Set Measuring Income Inequality." The World Bank Economic Review I0:565-59I.

Dixon, William J. and Terry Boswell. 1996. "Dependency, Disarticulation and Denominator Effects: Another Look at Foreign Capital Penetration." American Journal of Sociology 102: 543-562.

Firebaugh, Glenn. 1996. "Does Foreign Capital Harm Poor Nations? New Estimates Based on Dixon and Boswell's Measure of Capital Penetration." American Journal of Sociology 102: 563-575.

Firebaugh, Glenn. 1999. "Empirics of World Income Inequality." American Journal of Sociology 104: 1597-1630.

Frank, Andre Gunder. 1998. ReOrient: Global Economy in the Asian Age. Berkeley: University of California Press.

Goody, Jack. 1996. The East in the West. Cambridge: Cambridge University Press. Gustafsson, Bjorn, and Mats Johansson. 1999. "In Search of Smoking Guns: What Makes Income Inequality Vary over Time in Different Countries?” American Sociological Review 64: 585-605.

Korzeniewicz, Roberto Patricio and Timothy Patrick Moran. 1997. "World Economic Trends in the Distribution of Income, 1965-1992." American Journal of Sociology IO2: 1000-IO39.

Kuznets, Simon. 1955. "Economic Growth and Income Inequality." American Economic Review 45: I-28.

Nielsen, Francois. 1994. "Income Inequality and Industrial Development: Dualism Revisited." American Sociological Review 59: 654-677.

Passè-Smith, John T. 1998. "The Persistence of the Gap Between Rich and Poor Countries: Taking Stock of World Economic Growth, 1960-1993," in Development and Underdevelopment: The Political Economy of Global Inequality, edited by Mitchell A. Seligson and John T Passè-Smith. Boulder, Colo.: Lynne Reiner

Pomeranz, Kenneth. 2000. The Great Divergence: China, Europe, and the Making of the Modern World Economy. Princeton: Princeton University Press.

Sanderson, Stephen K., ed. 1995. Civilizations and World-Systems: Studying WorldHistorical Change. Walnut Creek, Calif.:Altamira.

Summers, Robert, Alan Heston, Bettina Aten, and Daniel Nuxoll. 1994. Penn World Table (PWT) Mark 5.6a Data. Center for International Comparisons, University of Pennsylvania.
Wallerstein, Immanuel. 1974. The Modern World-System: Capitalist Agriculture and the Origins of European World-Economy in the Sixteenth Century. New York: Academic Press.

Wong, R. Bin. 1997. China Transformed: Historical Change and the Limits of European Experience. Ithaca: Cornell University Press. 